\title{
Iranian EFL Learners' Writing Problems: A Move towards Solution
}

\author{
Maryam Sharafi-Nejad (Corresponding author) \\ School of Educational Studies \\ Universiti Sains Malaysia, 11800, Penang, Malaysia \\ E-mail: msn12_edu085@student.usm.my
}

Shohreh Raftari

Faculty Member of Medicine Department

University of Medical Sciences, Kerman, Iran

E-mail: Raftari2004@yahoo.com

Shaik Abdul Malik Mohamed Ismail

School of Educational Studies

Universiti Sains Malaysia, 11800, Penang, Malaysia

E-mail: samalik@usm.my

Lin Siew Eng

School of Educational Studies

Universiti Sains Malaysia, 11800, Penang, Malaysia

E-mail: selin@usm.my

Received: Sep. 8, 2016 Accepted: Nov. 20, 2016 Published: November 20, 2016

doi:10.5296/jse.v6i4.10203 URL: http://dx.doi.org/10.5296/jse.v6i4.10203

\section{Abstract}

Writing connotes the declaration or expression of thoughts, feelings, plans and wishes in a 
composed form that demands skills and expertise as opposed to knowledge. Skillful writing calls for diligent work, perusing or reading, composing through reaching inferences from perusing materials and long period of practice. This study seeks to investigate the problems and identify the practical needs of writing skill in English as Foreign Language (EFL) context with special focus on Iranian citizens studying in Universiti Sains Malaysia (USM). In Iran, learning English language appears cumbersome for learners because it is handled as a foreign language. Hence, the leaners are confronted with plethora of problems in writing the language because it is not utilized in real life conversation or situation. In order to achieve its objectives, the study administered questionnaires to the respondents to elicit information on the difficulties confronting them while learning English as Foreign Language and their pragmatic needs.

Keywords: English writing, EFL context, language learning, writing process, problems and practical needs 


\section{Introduction}

Writing is a framework for interpersonal communication that utilizes different forms of language which serves a useful role in our professional and personal lives (see Jalaludin, 2011). It is a fundamental criterion for measuring academic success in academia, and students strive for improvement and mastery of the skill of writing English language (see Hamed, 2012).

One of the most important aspects of communication is writing. As posited by (Akkaya \& Kirmiz cited in Gholaminejad et al. 2013, 1138) "writing is the expression of feelings, thoughts, desires and plans in black and white". Moreover, writing plays a crucial role in the teaching-learning process because it is the medium through which learners are assessed or evaluated. Among the four prominent English language skills namely, speaking, listening, reading and writing, the latter is considered as the most cumbersome.

Jahin \& Idrees (2012) noted that writing appears cumbersome irrespective of whether native or non-native learners because each writer or author is expected to strike a balance among various facets in his/her writing such as audience, content, purpose, organization, mechanics, vocabulary, etc. Thus, in the context of learning English as foreign language, writing skills become very troublesome to learners because the language is not used in practical or real life conversation. For instance, much importance is not accorded the learning of English language writing skill in a country such as Iran where English language is seen as foreign language. Consequently, the English syllabus adopted in the institutions remains traditional in nature. Though the Iranian government approved the syllabus and textbooks for the teaching and learning of English language in the country but much attention is not given to writing skills. The syllabus and textbooks basically concentrate on reading skill, vocabulary, grammar, listening and speaking. In this kind of EFL setting, for learners to improve on the mastery of writing skills and get the desired results, the importance of intensive practicing of writing skill cannot be overemphasized.

The development of the four main language skills is involved in the teaching of mother tongue. For instance, the reading and listening skills entail the comprehension skills while writing and speaking skills are concerned with the expression skills. Though these four main skills have different definitions, but they are interwoven in utilization as communication tools known as language. Also, the learning and practice of any of these basic communication skills could influence the development of the others. According to Sever (2004), the writing skill is not seen as a distinct skill from the other communication skills because of its interaction with the other skills. Apart from being a language skill, writing is a technique that promotes greater level of thinking. It is a complicated task that involves various steps and stages that demands relevant cognitive control mechanism such as planning, synthesizing, transforming, and reviewing (see Maltepe, 2006: 21).

Written expression is the medium of achieving success in other lessons, and this implies that one can encounter challenges in other lessons if the written expression is irregular and disorder. Hence, it becomes fundamental for students to obtain a certain minimum level of writing skill. According to Akyol (2006: 93), "as children's writing skills develop, their skills of transferring knowledge, revision and organization of thoughts will be more effective. 
This will facilitate their higher level of writing to emerge. However, individuals whose writing skills have not developed fail to interpret the text that they are reading and integrate with their own background knowledge, thus ending up copying the original text, which is originally aimed for transferring knowledge”

Tompkins (1982) highlighted seven essential reasons for the involvement of learners in creative writing of stories. These include; for entertainment; fostering of artistic expression; exploration of the functions and values of writing; stimulation of imagination; clarification of thinking; searching for identity; as well as learning to read and write. In view of these convincing reasons, it is difficult to provide justification why creative writing is not made an essential aspect of the elementary school classroom activity. Therefore, it becomes fundamental to clarify the importance of writing to parents and administrators who erroneously classify creative writing as trivial play similar to a recess.

\section{Literature Review}

Effective writing skills could promote the chances of students' success (Alexander, 2008). On the importance of writing to learning, Suleiman (2000) posited that writing is a veritable tool of language. Thus, every curriculum of reading and language should take into consideration the multidimensional nature of writing in instructional practices, the procedures of evaluation and language development.

It is fundamental to learn English language as a prerequisite in order to improve the reading comprehension and the quality of knowledge of students in every field or subject of study. This accounts for the reason why in non-English language countries such as Iran, every student irrespective of field of study is required to pass two or three ESP courses. However, students studying English language have more enthusiasm to learn how to read English texts in addition to their mother tongue. Hence, the reading comprehension ability of students thrives better than their writing skills among students studying English language in Iran. Despite the students' great reading skills and competence, their scores in essay writing and content are still below expectations among English students. The reason that could be adduced for this subpar performance is inadequate writing skills or miniature proficiency in essay tests writing. One of the principal problems facing Iranian EFL students irrespective of their fields of study is their inability to effectively communicate in English language after graduation from the university. This arises from their inability to be proficient in English language which ultimately affects their academic success particularly, writing skill that is essential for conveying their knowledge.

Besides, the possession of great writing skills could have a reflective impact on our lives. Though writing could be an art, but it is the responsibility of the artist to produce the masterpiece. Currier (2008) submitted that in the absence of practice of basic and competent writing skills, it is difficult to produce fictional proficient works of written art and influence lives. Analogously, Suleiman (2000) opined that the multidimensional nature of writing in instructional practices, assessment procedures, and language development should be taken into consideration in every reading and language art program. This is because the examination of the multidimensional nature of the process of writing enhances the 
understanding of the fundamentals of writing.

In the words of Hand et al. (2007, p. 34) posited that "you can have the greatest technical skills in the world, but without solid communication skills, who will know and who can understand?" This further underscores the progression of ESL instructions from oral to written communication.

Since words have the enormous power to influence and encourage others, it is essential for students prior to graduation from school to have proficiency in writing skills rather than the increasingly concentration of academic activities primarily on final course tests (Currier, 2008).The most popular and widely accepted means of examining academic attainment of students are course tests, albeit there are other means of assessing the academic and general success of students (Currier, 2008). Although ignoring the importance of such course tests is not an option, but more emphasis should also be placed on the mastery of writing skills during the period of study.

Several studies have showed the place of writing skills in EFL context. Writing is perceived as a complex and challenging skill to master (Graham, Harris \& Mason, 2005). Azizifar, Koosha and Lotfi (2010) investigated the textbooks of Iranian English Language Teaching (ELT) and revealed that the prescribed materials concentrate mainly on mechanical drills with little or no emphasis on motivating the learners to acquire and develop communication skills.

Dastjerdi and Samian (2011: 65-76) asserted that "Iranian EFL learners have frequent cohesion anomalies which they attributed to the learners' poor linguistic (especially syntactic and semantic) awareness as well as inaccurate knowledge of English cohesion rules". Similarly, Shokrpour \& Fallahzadeh, (2007) showed that learners of English as a foreign language are confronted with diverse problems and challenges such as vocabulary, grammar, spelling, punctuation, organization, among others. Moreover, Hosseini et al. (2013: 02) submitted that the inability of learners of EFL to communicate in English and "their weaknesses in English proficiency influence their academic success, especially in writing skill which is necessary to convey their knowledge”.

\section{Objectives}

The purpose of this study is to highlight the common writing skill difficulties faced by Iranian EFL learners in Universiti Sains Malaysia (USM) and suggest possible solutions on how to achieve competency in writing EFL. It also seeks to determine the practical needs of Iranian EFL learners vis-a-vis writing skill.

\section{Methodology}

The population of the study consists of Iranians studying English as a foreign language in Universiti Sains Malaysia (USM), from which a sample of twenty-two students was drawn. A questionnaire with both open-ended and close-ended questions as well as two types of subjective questions was designed to elicit information from the respondents.

\section{Result and Discussion}


A comprehensive discussion of the study findings is presented here:

\section{Section A}

It is obvious that not much national concentration or attention is accorded writing skill as expected. The results of the responses on the questionnaire showed that $40 \%$ of the responses indicated that more emphasis is placed on reading skill in EFL context of Iran while $30 \%$ of the responses indicated that writing skill is given much attention. The results revealed that the primary purpose of teaching writing skill in EFL context is to enable the learners to pass their examination and utilize it as a medium of communication only in the classroom setting.

\section{Section B}

The result also show that students are convenient to write only mail and short messages whereas they did not utilize the writing skill as a medium of communication for writing letters, notices, reports, etc. The respondents indicated that their first priority of learning writing skill is to enable them write messages and mails, while the least priority is to enable them write letters of complaint. The respondents also showed that they are mostly confronted with the problem of grammar when writing.

\section{Section C}

Based on the results of the study in table 1, the ability and inability of the respondents to compose ideas are very close. The percentages of responses from questions 5-12 of the questionnaire indicated that $35 \%$ of the respondents possess the ability to compose their ideas, thoughts and feelings and can effectively complete any piece of writing, while $30 \%$ of the respondents are unable to do so. Thus, despite its difficulty, most of the respondents have keen interest in writing, albeit it appears hard for them to commence a piece of writing. Another fundamental issue which 50 percentage of the respondents alluded to is difficulty in the organization of information for writing. Furthermore, $25 \%$ of the respondents disagreed that they can improve their writing by editing words, spelling, vocabulary, etc., while $30 \%$ of the respondents agreed that their writing skills can be improved through editing words, spelling, vocabulary, etc. However, the respondents were not certain whether they are satisfied with their writing performances or whether they follow a particular sequence in writing. Finally, it was unanimously agreed by the respondents that their communication skills can be improved through writing.

Table 1.

\begin{tabular}{|l|c|c|c|c|c|}
\hline $\begin{array}{l}\text { Scale } \rightarrow \\
\text { Questions }\end{array}$ & 5 & 4 & 3 & 2 & 1 \\
\hline Q. 5 & $20 \%$ & $45 \%$ & $10 \%$ & $15 \%$ & $10 \%$ \\
\hline Q. 6 & $05 \%$ & $30 \%$ & $10 \%$ & $35 \%$ & $20 \%$ \\
\hline Q. 7 & $05 \%$ & $40 \%$ & $15 \%$ & $30 \%$ & $10 \%$ \\
\hline Q. 8 & $10 \%$ & $50 \%$ & $15 \%$ & $25 \%$ & $00 \%$ \\
\hline Q. 9 & $20 \%$ & $30 \%$ & $20 \%$ & $25 \%$ & $05 \%$ \\
\hline Q. 10 & $00 \%$ & $35 \%$ & $50 \%$ & $15 \%$ & $00 \%$ \\
\hline
\end{tabular}




\begin{tabular}{|l|l|l|l|l|l|} 
Q. 11 & $05 \%$ & $20 \%$ & $40 \%$ & $30 \%$ & $05 \%$ \\
\hline Q. 12 & $35 \%$ & $25 \%$ & $10 \%$ & $25 \%$ & $05 \%$ \\
\hline
\end{tabular}

Note: Scale- $5=$ strongly agree; $4=$ agree; $3=$ no opinion; $2=$ disagree; $1=$ strongly disagree.

\section{Section D}

In real life context, English language lacks publicity and does not get prominent recognition in national setting. As for writing skill in EFL context, the respondents have little remarks, they indicated that English language is merely an aspect of the syllabus in Iran. They noted that in EFL context, students merely write so that they can pass their examinations. The respondents however suggested that to make English language familiar and famous, emphasis should be given to writing, speaking and listening skills. Additionally, apart from using English language in the classroom setting, the learners should also be encouraged to utilize the language as a medium of communication and interaction outside the classroom environment in order to improve their skills. Two questions were asked in this section and in the first one, all of the students want to improve their writing skills through reading. Students indicated that their writing performances can be enhanced through improvement in grammar, vocabulary skill and regular practice of writing. They believed that through reading of newspapers, magazines, journals and books, their writing proficiency can be better enhanced.

\section{Conclusion}

Writing skills can be major criteria towards better academic position and greater educational success. However, this good advice will be lost if students do not believe the importance of writing skills in helping them achieve academic mastery. The planner and designer of the curriculum of EFL setting should emphasize the immediate importance of writing skill due to its international demands. They need to concentrate on how to make learner acquire proficiency in writing skill in a systematic plan in order to enable them write effectively. The results of the study have demonstrated that writing skill requires enormous efforts for the twenty-two Iranian EFL students of USM. Although the result is based on only twenty-two samples, it can be inferred that writing skill needs to be given much more emphasis and practice in EFL context.

\section{Acknowledgements}

Our special thanks to Universiti Sains Malaysia for their support in providing USM Fellowship Scheme for this study.

\section{References}

Akkaya, N., \& Kirmiz, F. S. (2013). Relationship between Attitudes to Reading and Time Allotted to Writing in Primary Education, Procedia Social and Behavioral Sciences, 4742-4746, 2010. Cited in R. Gholaminejad, A. Moinzadeh, M. Youhanaee, H. Ghobadirad, Writing Attitudes of Iranian EFL Students: A Qualitative Study. Journal of Language Teaching and Research4(5), 2013, 1138.

Akyol, H. (2006). Türkçe ö $\div$ retim yöntemleri. Ankara: Kök YayÕncÕlÕk. 
Alexander M. (2008). Good writing leads to good testing. 2008, Retrieved from Http://www.stickyminds.com/sitewide.asp?ObjectId=3391\&Function=edetail\&ObjectType= ART on March 262012.

Azizifar, A., Koosha, M., and Lotfi, A. R. (2010). An Analytical Evaluation of Iranian High School ELT Textbooks from 1970 to the Present, Procedia Social and Behavioral Sciences, 3, 2010. http://dx.doi.org/10.1016/j.sbspro.2010.07.010.

Currier, D. (2008). Essay on the importance of writing - need feedback please. Asian ESL Journal. Retrieved from Gloria, Essay Writing Feedback/EssayForum.com on 8/17/2010 Journal 80 (2008) 183-199.

Dastjerdi, H., \& Samian, H. S. (2011). Quality of Iranian EFL learners' Argumentative Essays: Cohesive Devices in Focus. Mediterranean Journal of Social Sciences, 2(2), 2011, 65-76.

Graham, S., Harris, K. R., \& Mason, L. (2005). Improving the Writing Performance, Knowledge, and Self-efficacy of Struggling Young Writers: The Effects of Self-regulated Strategy Development, Contemporary Educational Psychology, 30(2). http://dx.doi.org/10.1016/j.cedpsych.2004.08.001

Hamed, J.J. (2012). The effect of peer reviewing on writing apprehension and essay writing ability of perspective EFL teachers. The Australian Journal of teacher education, 37(11), 60-84. http://dx.doi.org/10.14221/ajte.2012v37n11.3

Hand B., Hohenshell L., \& Prain V. (2007). Instructional Science, 35(4).

Hosseini, M., Taghizadeh, M. E., Abedin, M. J. Z., \& E. Naseri. (2013). In the Importance of EFL Learners' Writing Skill: Is There Any Relation between Writing Skill and Content Score of English Essay Test? International Letters of Social and Humanistic Sciences, 6(1). http://doi:10.18052/www.scipress.com/ILSHS.6.1.

Jahin, J. H., \& Idrees, M. W. (2012). EFL Major Student Teachers' Writing Proficiency and Attitudes Towards Learning English. Journal of Taibah University, 4(1).

Jalaluddin, I. (2011). Teacher's assistance in developing rural learners' writing skills and writing self-efficacy: A case study. Unpublished Ph.D. Theses. University Kebangsan Malaysia.

Maltepe, S. (2006). YaratÕcÕ Yazma YaklaúÕmÕ AçÕsÕndan Türkçe Derslerindeki Yazma Süreçlerinin ve Ürünlerinin De $\div$ erlendirilmesi [Evaluation of writing processes and products in Turkish lessons from the creative writing approach], Ph.D, Ankara: Ankara Üniversitesi.

Sever, S. (2004). Türkçe ö $\div$ retimi ve tam ö $\div$ renme [Turkish instruction and whole learning]. Ankara: AnÕ YayÕncÕlÕk.

Shokrpour, N., \& Fallahzadeh, M. H. (2007). A Survey of the Students and Interns' EFL Writing Problems in Shiraz University of Medical Sciences. The Asian EFL Journal Quarterly, 9(1). 


\section{Macrothink}

Suleiman, M. F. (2013). The Process and Product of Writing: Implications for Elementary School Teachers (ERIC Digest, ERIC, 2000) cited in M. Hosseini, M. E. Taghizadeh, M. J. Z. Abedin and E. Naseri, In the Importance of EFL Learners' Writing Skill: Is There Any Relation between Writing Skill and Content Score of English EssayTest? International Letters of Social and Humanistic Sciences 6(1). http://doi:10.18052/www.scipress.com/ILSHS.6.1.

Suleiman M. F. (2000). The process and product of writing: Implications for elementary school teachers. ERIC Digest, ERIC Identifier ED 442299.

Tompkins, G. E. (1982). Seven Reasons Why Children Should Write Stories. Language Arts, 59(7), 718-21. 